\title{
Podobieństwa i różnice w zwalczaniu bojowników kaukaskich w okresie sprawowania władzy przez Borysa Jelcyna i Władimira Putina w Federacji Rosyjskiej
}

\begin{abstract}
Streszczenie: Analizując politykę Federacji Rosyjskiej wobec zagrożenia terrorystycznego, pochodzącego z Kaukazu Północnego, należy stwierdzić, że Moskwa przez wiele lat nie miała wypracowanej jednej i spójnej koncepcji rozwiązania tego problemu. W ostatniej dekadzie XX w. rosyjska strategia polegała w dużej mierze na reagowaniu na zaistniałe kryzysy. Polityka ta, doprowadziła do porażki w pierwszej wojnie czeczeńskiej oraz przyczyniła się do wzrostu niestabilność całego regionu Kaukazu Północnego. Rosjanie na początku XXI w. zmienili strategię walki z terroryzmem pochodzącym z Kaukazu Północnego, realizując tzw. politykę czeczenizacji. Polega ona na tym, że przedstawiciele samych narodów kaukaskich zwalczają terrorystów.
\end{abstract}

Słowa kluczowe: Federacja Rosyjska, terroryzm islamski, Kaukaz Północny, Borys Jelcyn, Władimir Putin, Ramzan Kadyrow

\footnotetext{
nalizując politykę Federacji Rosyjskiej wobec zagrożenia terroryAstycznego, pochodzącego z Kaukazu Północnego, należy stwierdzić, że Moskwa przez wiele lat nie miała wypracowanej jednej i spójnej koncepcji rozwiązania tego problemu. W ostatniej dekadzie XX w. rosyjska strategia polegała $\mathrm{w}$ dużej mierze na reagowaniu na zaistniałe kryzysy (Falkowski, Marszewski, 2010, s. 31). Polityka ta, nie przynosiła dużych sukcesów, bowiem doprowadziła do porażki w pierwszej wojnie czeczeńskiej oraz przyczyniła się do wzrostu niestabilność całego regionu Kaukazu Północnego. Niestabilność z kolei doprowadziła do odrodzenia islamskiego, a co za tym idzie, spowodowała wzrost popularności muzułmańskich radykałów. Postępująca islamizacja oraz derusyfikacja tego obszaru są coraz bardziej widoczne i gro badaczy tego regionu skłania się ku tezie, że republiki leżące na Kaukazie Północnym, są tak odmienne kulturowo od rosyjskiego centrum, iż nie powinno się ich traktować jako integralnej części samej Federacji (Markedonov, 2013).
} 
Stosowane przez radykałów metody terrorystyczne, miały doprowadzić do opuszczenia przez Rosjan całego Kaukazu i utworzenia tam islamskiego państwa, w którym obowiązywałoby prawo szariatu (Falkowski, Marszewski, 2010, s. 22). Od 2007 r. jest to główny cel największej organizacji terrorystycznej działającej na obszarze Kaukazu Północnego, czyli tzw. Emiratu Kaukaskiego powołanego przez Doku Umarowa. Wg koncepcji jego twórców, w skład islamskiego państwa na Kaukazie Północnym ma wchodzić pięć wilajetów, których obszary pokrywają się z granicami poszczególnych republik i krajów, będących częścią Federacji Rosyjskiej. Możemy więc tutaj wyróżnić wilajety: Dagestanu, Czeczenii, Inguszetii, wspólne wilajet Kabardy, Bałkarii i Karaczaju, a także Kraju Krasnodarskiego oraz Stawropolskiego. Przez cały okres istnienia Emiratu Kaukaskiego, nie powołano jednak żadnych struktur państwowych. Trzeba jednak zauważyć, że od śmierci Doku Umarowa (czyli od 2013 r.) organizacja ta przeżywa duży kryzys organizacyjny i tożsamościowy, co ma realny wpływ na skuteczność prowadzonych przez nią działań.

\section{Działania bojowników kaukaskich jako przykład zagrożeń asymetrycznych}

Działania bojowników kaukaskich (tworzących od 2007 r. Emirat Kaukaski, wcześniej walczących przeciwko Federacji Rosyjskiej podczas pierwszej oraz drugiej wojny czeczeńskiej) przez wiele lat miały charakter aktów terrorystycznych, które zaliczane są do tzw. zagrożeń asymetrycznych. Zagrożenia te, stanowią obecnie ogromne wyzwanie dla władz każdego państwa, które muszą mieć na uwadze bezpieczeństwo obywateli. Jakie zatem cechy wspólne będą miały wszelkiego rodzaju zagrożenia asymetryczne? Jako pierwszą cechę z pewnością możemy wyróżnić pozapaństwowość. Aby konflikt miał taki charakter, jedna ze stron nie może być państwem (czyli nie może posiadać wszystkich atrybutów państwowości - mieć ludności, terytorium i władzy) (Pietraś, 2003, s. 168-169). Ten brak jasno określonego „obszaru występowania” powoduje, że państwo, które musi się mierzyć z tym zagrożeniem, ma trudności ze zlokalizowaniem agresora. W takiej sytuacji podmiot, który jest źródłem tego typu zagrożeń, nie będzie się bał, że napotka na skuteczne działania odwetowe. Kolejną cechą zagrożeń asymetrycznych jest ich quasi-militarny charakter. Dotyczy to sytuacji, w której użyto siły, jednak w inny sposób niż w tradycyjnym konflikcie zbrojnym. Celem agresora nie jest bowiem 
częściowe (czy też nawet całkowite) zniszczenie potencjału wojskowego atakowanego państwa, ale głównie wywołanie poczucia strachu wśród społeczeństwa lub też wymuszenie podjęcia jakiejś decyzji przez konkretne władze. Jeszcze inną cechą zagrożeń asymetrycznych, będzie ich nieprzewidywalność. Tak jak w przypadku konfliktów tradycyjnych, bardzo łatwo można wskazać obszar działań (np. front, na którym to ścierają się dwie armie), tak w zagrożeniach asymetrycznych jest to niemożliwe (Madej, 2012, s. 82). Przy tego typu niebezpieczeństwach, podmiot stanowiący ich źródło może używać wszystkich metod, aby tylko osiagnąć zamierzone cele. Ta swoista totalność powoduje, że trudno przewidzieć miejsce oraz czas takiego działania. Omawiając zagrożenia asymetryczne, można również stwierdzić, że ich charakterystyczną cechą będzie relatywnie małe zagrożenie dla tradycyjne rozumianego bezpieczeństwa państw, jako jednostek geopolitycznych. W przypadku tradycyjnych konfliktów zbrojnych, klęska militarna wiązała się z utratą części (bądź też nawet całości terytorium) oraz dużymi stratami materialnymi. W przypadku zagrożeń asymetrycznych skala strat (mierzona w tym aspekcie) jest o wiele niższa, lub nie ma jej wcale. Mówiąc zatem o zagrożeniach asymetrycznych, będziemy koncentrowali się na takich wyzwaniach dla bezpieczeństwa wewnętrznego państwa, jak: terroryzm, przestępczość zorganizowana (najczęściej transnarodowa), walka informacyjna (czy informatyczna), a także groźba użycia broni masowego rażenia.

\section{W jaki sposób państwo może skutecznie bronić się przed terroryzmem?}

Terroryzm (niezależnie w jakiej postaci) stanowi zagrożenie dla bezpieczeństwa wewnętrznego każdego państwa. Bezpieczeństwo wewnętrzne (inaczej narodowe) należy rozumieć jako: „stan uzyskany w rezultacie odpowiednio zorganizowanej obrony i ochrony przed zagrożeniami tak zewnętrznymi, jak i wewnętrznymi” (Słownik, 2002, s. 14). Biorąc pod uwagę powyżej przytoczoną definicję, można więc stwierdzić, że do najważniejszych obowiązków państwa należy zapewnienie ochrony jego obywatelom, przed zagrożeniami militarnymi oraz niemilitarnymi.

Omawiając strukturę systemu antyterrorystycznego (posługując się wysokim stopniem ogólności, bez omawiania konkretnych systemów antyterrorystycznych występujących w poszczególnych państwach) można za Bartoszem Bolechówem wskazać siedem jego elementów. Będą nimi: 
neutralizacja samych przyczyn terroryzmu, zapobieganie radykalizacji, która może doprowadzić do przemocy politycznej, ograniczanie możliwości i skuteczności działań organizacji terrorystycznych, odstraszanie, obrona bezpośrednia, minimalizowanie negatywnych skutków udanych zamachów terrorystycznych oraz przegląd systemu i projektowanie zmian. Warto w tym momencie zaznaczyć, że w ramach poszczególnych systemów krajowych istnieją oczywiście różne instytucje, które w ramach swoich obowiązków muszą realizować pewne zadania (Bolechów, 2012, s. 273-274).

Aby mówić o skutecznej ochronie obywateli, każda władza państwowa musi prowadzić aktywną politykę antyterrorystyczną. Działania te muszą być jednak podejmowane równolegle na kilku polach. Wymaga to przede wszystkim poczynań na płaszczyźnie prawnej, organizacyjnej, wykonawczej oraz społecznej (Adamczyk, 2011, s. 135). Pierwsza z nich będzie dotyczyła uchwalania odpowiednich ustaw przez władzę ustawodawczą, w których będą znajdowały się zapisy, dotyczące kompetencji oraz metod działania poszczególnych organów państwa $\mathrm{w}$ walce $\mathrm{z}$ terroryzmem. Biorąc pod uwage płaszczyznę organizacyjną, każde państwo, aby skutecznie walczyć z tym zagrożeniem, musi stworzyć krajowy system antyterrorystyczny. Będzie się na niego składać nie tylko istnienie odpowiedniego centrum (które ma planować i koordynować pracę różnych służb i organów), ale także wypracowanie odpowiednich procedur postępowania poszczególnych elementów całego systemu. Dotyczyć to będzie oczywiście również wymiany informacji (pomiędzy elementami systemu oraz we współpracy z innymi państwami), a także doboru wykwalifikowanych pracowników. Zatrudnianie osób pod względem ich merytoryczności z pewnością ma duży wpływ na samo dobre funkcjonowanie całego systemu. Płaszczyzna wykonawcza będzie z kolei dotyczyła głównie ciagłego monitorowania wszelkich zagrożeń, a także optymalnego wykorzystania posiadanego potencjału przy ich niwelowaniu. Płaszczyzna społeczna to $\mathrm{z}$ kolei w największym stopniu edukowanie obywateli, jak należy reagować na same podejrzenia lub też symptomy działalności terrorystycznej w danym kraju (Adamczyk, 2011, s. 136). Każdemu państwu (zwłaszcza temu, w którym istnieje duże zagrożenie terrorystyczne) powinno zależeć na tym, aby tak wychowywać swoich obywateli, żeby ci mieli świadomość wystapienia zagrożenia, umieli je rozpoznać i wiedzieli jak w takiej sytuacji się zachowywać.

Posługując się podziałem zaproponowanym przez Raula Andrzeja Kostę w książce Terroryzm jako zagrożenie dla bezpieczeństwa cywilizacji zachodniej $w X X I w$. możemy stwierdzić, że metody zwalczania terro- 
ryzmu dzielą się na metody: polityczne, militarne oraz zmienne. Metody polityczne będą to wszelkiego rodzaju deklaracje, apele, czy też porozumienia lub umowy podpisywane pomiędzy poszczególnymi państwami, zawierające postulaty zwalczania terroryzmu. Do nich z pewnością będziemy zaliczali też negocjacje podejmowane przez polityków (czy też inne osoby) z samymi terrorystami bądź też ich przedstawicielami. W długiej perspektywie metody polityczne są najbardziej skutecznymi sposobami zwalczania terroryzmu. Często stosowaną metodą zwalczania tego typu zagrożeń (przez Stany Zjednoczone czy Federację Rosyjską) jest używanie siły militarnej. Polega ona na bezpośrednim zaangażowaniu wojska (bądź też innych struktur siłowych) w miejscu, gdzie swoje siedziby mogą mieć organizacje terrorystyczne bądź sami jej członkowie. Jest to bardzo spektakularny sposób walki z terroryzmem, jednak nie zawsze przynosi on sukcesy w dłuższej perspektywie czasowej. Jest to skuteczna metoda $\mathrm{w}$ walce $\mathrm{z}$ państwami popierającymi terrorystów, ale biorąc pod uwagę charakter zagrożeń asymetrycznych, niekoniecznie z nimi samymi. Zmienne (cywilno-wojskowe) zwalczanie terroryzmu będzie z kolei polegało na stosowaniu jednych i drugich metod. Przykładem mogą być działania podejmowane podczas konfliktu arabsko-izraelskiego (Kosta, 2007, s. 102-117).

\section{Zwalczanie terroryzmu w Federacji Rosyjskiej na płaszczyźnie prawnej}

Ramy prawne walki z terroryzmem w Federacji Rosyjskiej określone zostały w aktach rangi ustrojowej, ustawach oraz także w dokumentach opracowywanych przez organy władzy wykonawczej. W okresie 1991-1999 kwestie związane z kierunkami polityki bezpieczeństwa wewnętrznego zostały zawarte w dwóch dokumentach bazowych - w Konstytucji Federacji Rosyjskiej oraz w ustawie $O$ bezpieczeństwie. Artykuł 2 Konstytucji głosi, iż człowiek i jego prawa są wartością najwyższą. Zatem do najważniejszych zadań państwa rosyjskiego należy zapewnienie obywatelom prawa do życia (Zwalczanie, 2014, s. 255).

5 marca 1992 r. została przyjęta ustawa $O$ bezpieczeństwie, która przez wiele lat była kluczowym dokumentem, określającym koncepcje bezpieczeństwa wewnętrznego Rosji (Azjatyckie, 2013, s. 157). W akcie tym, zdefiniowano czym jest bezpieczeństwo narodowe. Określono, że jest to stan, w którym poszczególnym obywatelom oraz także całemu społe- 
czeństwu Federacji Rosyjskiej zapewnia się ochronę przed zagrożeniami zarówno zewnętrznymi, jak i wewnętrznymi. Zapisano w niej także, że tylko państwo (dysponując określonymi środkami) może skutecznie zapewnić bezpieczeństwo swoim obywatelom (Duraj, 2015).

Ustawa Federalna $O$ walce z terroryzmem, która została uchwalona w 1998 r., określała z kolei główne zasady walki z zagrożeniem terrorystycznym (Walka, 2005, s. 145). Wskazano w niej, że kluczowe dla bezpieczeństwa, będzie przede wszystkim zapobieganie terroryzmowi, a także zapewnienie ochrony obywatelom. Znalazły się w niej również zapisy mówiące o tym, że każda osoba, które podejmie działalność terrorystyczną, poniesie odpowiedzialność karną. Zaznaczono, że państwo ma prawo wykorzystywać wszelkiego rodzaju środki, by skutecznie walczyć z zagrożeniem terrorystycznym. Wskazano tutaj cały katalog środków: od militarnych poprzez polityczne, ekonomiczne, aż po legislacyjne (Mickiewicz, 2010/2011, s. 120). Określono także, jakie organy i instytucje są w największym stopniu odpowiedzialne za walkę z terroryzmem w Federacji Rosyjskiej. Centralną rolę w systemie antyterrorystycznym miały pełnić takie organy i instytucje (z uwzględnieniem ich struktur terenowych), jak: Federalna Służba Bezpieczeństwa, Ministerstwo Spraw Wewnętrznych, Służba Wywiadu Zagranicznego i Ministerstwo Obrony (Федеральный, 1998).

Warto także wspomnieć, że w rosyjskim kodeksie karnym (przyjętym 13 czerwca 1996 r.), znalazły się przepisy, określające sankcje dla osób dopuszczających się przestępstw o charakterze terrorystycznym lub ekstremistycznym. Dokładny ich opis znajduje się w rozdziale IX (zatytułowanym: „Przestępstwa przeciwko bezpieczeństwu publicznemu i porządkowi publicznemu”), X (zatytułowanym: „Przestępstwa przeciwko władzy państwowej”) oraz XII (zatytułowanym „Przestępstwa przeciwko pokojowi i bezpieczeństwu ludzkości”) (Уголовный, 1996).

W okresie rządów Władimira Putina, zostały opracowane dwa dokumenty, w których to kompleksowo opisano kierunki polityki bezpieczeństwa państwa. W przyjętej w 2009 r. „Strategii bezpieczeństwa narodowego Federacji Rosyjskiej do 2020 r.” zawarto podobną definicję bezpieczeństwa narodowego do tej, jaka znalazła się w ustawie z 1992 r. Stwierdzono, że jest to zabezpieczenie jednostki, społeczeństwa oraz państwa przed zagrożeniami o charakterze zarówno wewnętrznym, jak i zewnętrznym. W dokumencie tym, wyraźnie wskazano, że terroryzm i ekstremizm religijny moga być źródłem zagrożeń dla bezpieczeństwa wewnętrznego i dlatego też, do zadań państwa należy ich zwalczanie (Обеспечение, 2009). Drugim bazowym dokumentem, określającym kierunki polityki wewnętrznej państwa 
(przyjętym w tzw. okresie putinowskim) jest ustawa $O$ bezpieczeństwie z 2010 r. W podobnym duchu (jak w ustawie O bezpieczeństwie z 1992 r. i „Strategii...” z 2009 r.) opisano zadania państwa w kwestii bezpieczeństwa narodowego (Федеральный, 2010).

Niezwykle istotnym aktem prawnym (z punktu widzenia antyterrorystycznego ustawodawstwa) jest ustawa z 2006 r. O przeciwdziałaniu terroryzmowi. Zawarte w niej zapisy w sposób kompleksowy regulują kwestie związane z tym zagadnieniem. Składa się na nią 27 artykułów, podzielonych na cztery bloki tematyczne. W bloku pierwszym wskazano czym jest terroryzm oraz zdefiniowano podstawowe zasady przeciwdziałania wobec tego zjawiska (Федеральньй, 2006). W części drugiej wskazano jakie kompetencje przysługują konkretnym organom w zwalczaniu terroryzmu. W bloku trzecim opisano z kolei czym jest operacja antyterrorystyczna, która może być przeprowadzona na terytorium Federacji Rosyjskiej. W ostatniej części ustawy (w artykułach 18-25) znalazły się zapisy mówiące $\mathrm{w}$ jaki sposób chronić pod względem prawnym oraz socjalnym osoby, które biorą czynny udział w zwalczaniu terroryzmu w Rosji (Terroryzm, 2009, s. 116-125). Warto także wspomnieć, że w okresie sprawowania rządów przez Władimira Putina przyjęto również: Ustawę Federalną O przeciwdziałaniu legalizacji dochodów, uzyskiwanych $w$ wyniku działalności przestępczej, i finansowaniu terroryzmu (w 2001 r.) oraz Ustawę Federalną O przeciwdziałaniu działalności ekstremistycznej (w 2002 r.) (Problemy, 2009, s. 413).

$\mathrm{Z}$ punktu widzenia walki z terroryzmem pochodzącym z Kaukazu Północnego (a szczególnie z Czeczenii) niezwykle ważne zmiany prawne przeprowadzono 16 maja 2002 r., kiedy to zwiększono zakres kompetencji cywilnych władz w Czeczenii. Wiązało to się oczywiście z ograniczeniem władz wojskowych w zbuntowanej republice (przede wszystkim Ministerstwa Obrony i Sztabu Generalnego). Szef administracji cywilnej zyskał kompetencje powoływania rządów oraz uzyskał również prawo samodzielnego mianowania dyrektorów administracji rejonowych.

\section{Sfera realizacyjna polityki Federacji Rosyjskiej wobec bojowników kaukaskich podczas sprawowania władzy przez Borysa Jelcyna oraz Wladimira Putina}

Analizując rosyjską politykę wobec Czeczenii (jako największego źródła terroryzmu islamskiego pochodzącego z Kaukazu Północnego) 
w ostatniej dekadzie XX w., należy stwierdzić, że w całym tym okresie miała ona charakter reaktywny (Konarzewska, 2013). Działania Moskwy wobec niepokornej republiki były tylko reakcją na zaistniałe kryzysy, a nie realizacją określonej polityki. Wynikało to $\mathrm{z}$ tego, że na początku lat 90-tych Rosja musiała się zmagać z innymi wewnętrznymi problemami, jakie pojawiły się w momencie rozpadu dawnego supermocarstwa. Rosyjskie elity musiały odpowiedzieć sobie na pytania: w jaki sposób utworzyć nowy system władzy w upadłym supermocarstwie oraz jak możliwie bezboleśnie przejść z gospodarki centralnie planowanej na gospodarkę wolnorynkową. Trzeba także pamiętać, że wówczas w Federacji Rosyjskiej trwała polityczna walka pomiędzy Michaiłem Gorbaczowem a Borysem Jelcynem o to, kto zostanie nowym przywódcą państwa. Zajęta konfliktem na najwyższym szczeblu władzy Moskwa, nie zdecydowała się na zastosowanie wariantu siłowego nawet $\mathrm{w}$ momencie ogłaszania niepodległości Czeczenii przez Dżochara Dudajewa. Dopiero w grudniu 1994 r. zdecydowano się na taki krok. Posługując się argumentem ,przywrócenia porządku konstytucyjnego", wprowadzono do Czeczenii wojska, by ponownie odzyskać kontrolę nad zbuntowaną republiką. Borys Jelcyn, podejmując taką decyzję był przekonany, że szybka i skuteczna akcja militarna, będzie dobrym argumentem $w$ walce politycznej z rosnącymi w siłę komunistami (pod przywództwem Giennadija Ziuganowa) oraz nacjonalistami (z Władimirem Żyrinowskim na czele) (Czeczenia, 2006, s. 35). Wierzył również, że zwycięstwo przyczyni się także do tego, że inne republiki, nie będą w przyszłości domagały się niepodległości, czy szerokiej autonomii. Do wojny parli również rosyjscy generałowie, którzy upatrywali w tym konflikcie wzmocnienie swojej politycznej roli w wewnętrznej rozgrywce. Wynik wojny ukazał jednak ogromną słabość, byłego już supermocarstwa. Poniesiona klęska militarna przyczyniła się nie tylko do osłabienia wpływów Kremla na całym Kaukazie Północnym, ale także w państwach Kaukazu Południowego. W porozumieniu podpisanym w sierpniu 1996 r. w Chasawjurcie, zawarto zapisy mówiące o wycofaniu się wojsk rosyjskich z Czeczenii oraz zobowiązano się, że umowa regulująca stosunki rosyjsko-czeczeńskie zostanie opracowana i podpisana w ciaggu najbliższych pięciu lat.

Podczas pierwszej wojny czeczeńskiej niezwykle istotnym wydarzeniem (biorąc pod uwagę zakończenie tej wojny) był zamach przeprowadzony w Budionnowsku. 14 czerwca 1995 r. bojownicy pod dowództwem Szamila Basajewa dokonali szturmu na miasto i zamknęli w szpitalu miejscową ludność (Jagnieża, 2014). Ponad 1800 zakładników 
przez 5 dni było przetrzymywanych przez oddział Basajewa. Negocjacje, które rozpoczęły się 17 czerwca i w których brał udział osobiście ówczesny premier Federacji Rosyjskiej Wiktor Czernomyrdin, były punktem zwrotnym podczas pierwszej wojny czeczeńskiej (Kuleba, 2007, s. 166). Władze rosyjskie zgodziły się bowiem na żądania terrorystów i tymczasowo wstrzymano działania wojenne w zbuntowanej republice. Ponadto, zezwolono napastnikom na powrót do Czeczenii w siedmiu autokarach. Zamachowcy po powrocie byli witani w republice jak zwycięzcy. Wydarzenia te, przyczyniły się do późniejszego rozejmu zawartego w Chasawjurcie (Falkowski, 2015, s. 8).

Warto także zaznaczyć, że w okresie 1996-1999 Rosjanie, podobnie jak na początku lat 90-tych, nie opracowali jednej i spójnej strategii działań wobec tej kaukaskiej republiki. Pozbawiona wsparcia finansowego z centrum Czeczenia, przez ponad cztery lata targana była różnymi konfliktami politycznymi, społecznymi oraz gospodarczymi. Ogromne rozczarowanie polityką prowadzoną przez Asłana Maschadowa doprowadziło do pogorszenia się nastrojów społecznych, a co za tym idzie do rozwoju islamskiego fundamentalizmu na tym obszarze. Wiązało się to również z napływem radykałów muzułmańskich z Bliskiego Wschodu na Północny Kaukaz. To ich działalność była jedną z głównych przyczyn interwencji wojskowej Rosjan w Czeczenii 1999 r. W sierpniu 1999 r. grupy bojowników kaukaskich dowodzone przez emira Chattaba oraz Szamila Basajewa przeprowadziły atak na Dagestan, w celu wyzwolenia tej republiki spod panowania rosyjskiego (Czeczenia, 2006, s. 126). Ponadto radykałowie muzułmańscy byli odpowiedzialni za zorganizowanie i przeprowadzenie zamachów terrorystycznych w Moskwie, Bujnacku i Wołgodońsku, w wyniku których zginęło ponad 300 rosyjskich obywateli (Falkowski, 2003, s. 30).

Wydarzenia związane z drugą wojną czeczeńską (którą rozpoczęto w 1999 r.), miały ogromny wpływ na Federację Rosyjską oraz na samą karierę polityczną Władimira Putina. Mianowany w 1999 r. na urząd premiera polityk, starał się od samego początku budować wizerunek męża stanu, który będzie w stanie uchronić Rosjan od zagrożenia terrorystycznego. Po serii zamachów w rosyjskich miastach, przeprowadzonych na jesieni 1999 r., wśród społeczeństwa panował ogromny strach i antyczeczeńskie nastroje. Po objęciu urzędu premiera, Putin w pierwszych swoich wywiadach zapewniał, że jednym z priorytetów jego rządu będzie bezwzględna walka z terrorystami. Ta ogromna popularność ówczesnego premiera, z pewnością miała duży wpływ na decyzję Borysa Jelcy- 
na z 31 grudnia 1999 r., dotyczącą jego ustąpienia z urzędu prezydenta, po której to Putin, przejął obowiązki głowy państwa (Falkowski, 2003, s. 31).

W trakcie drugiej wojny czeczeńskiej bojownicy kaukascy odpowiadali za zorganizowanie wielu zamachów, przeprowadzonych zarówno na Kaukazie Północnym, jak i w innych rejonach Federacji Rosyjskiej. Do najbardziej spektakularnych zamachów terrorystycznych z pewnością należały ataki przeprowadzone: na Dubrowce w 2002 r., w Biesłanie w 2004 r., czy na lotnisku Domodiedowo w 2011 r. Warto jednak zauważyć, że nie zawsze przynosiły one pożądane korzyści z punktu widzenia terrorystów.

Zamach na Dubrowce został przeprowadzony 23 października $2002 \mathrm{r}$. Dramat zakładników uprowadzonych przez Mowsara Barajewa trwał trzy dni. Podczas przedstawienia „Nord-Ost” grupa 40 terrorystów (wśród których było 18 tzw. „czarnych wdów”) wtargnęła do teatru na Dubrowce i uprowadziła ponad 900 osób. Żądaniem bojowników, było jak najszybsze zakończenie drugiej wojny w Czeczenii oraz wycofanie wszelkich oddziałów rosyjskich z tej republiki w ciagu tygodnia (Kaukaz, 2005, s. 163-164). Od samego początku było jasne, że władze rosyjskie nie spełnią żądań wystosowanych przez terrorystów. Pozorowane negocjacje (za które odpowiadał gen. Wiktor Kazancew) miały tylko dać niezbędny czas dwóm oddziałom specjalnym, które przygotowywały się do odbicia zakładników. 26 października (po trzech dniach od uprowadzenia) rozpoczęła się akcja odbicia zakładników, która to zakończyła się zabiciem wszystkich terrorystów oraz śmiercią 129 cywilów. Tak duża ilość śmiertelnych ofiar spowodowana była niewłaściwą akcją ratunkową, która przeprowadzona była w dużym chaosie. Brakowało szpitali polowych pod teatrem, a co najważniejsze lekarze i ratownicy medyczni, znajdujący się w karetkach nie dostali informacji, jakiego gazu użyły jednostki Alfy i Wympieła, rozpoczynając akcję antyterrorystyczną (Wolska, 2013, s. 29-31).

Po dwóch latach od wydarzeń na Dubrowce, doszło do kolejnego dużego zamachu zorganizowanego przez bojowników kaukaskich. W 2004 r. 33 terrorystów należących do grupy Szamila Basajewa opanowało szkołę nr 1 w Biesłanie w Osetii Północnej. Żądania terrorystów były bardzo podobne do tych, jakie wystosowali w 2002 r. Ich postulatem było zakończenie wojny w Czeczenii i wycofanie się oddziałów rosyjskich z tej republiki. Ponadto zażądali oni zwolnienia rebeliantów, schwytanych przez siły rosyjskie podczas ataku bojowników na Ingusze- 
tię w dniach 21-22 czerwca 2004 r. Po raz kolejny władze rosyjskie nie zamierzały spełnić żądań terrorystów. Na skutek nieudolnej akcji odbicia zakładników (organizowanej przez Specnaz) podczas tego zamachu zginęły 334 osoby (w tym 186 dzieci) (Czeczenia, 2006, s. 80-81).

Kolejnym dużym zamachem przeprowadzonym przez bojowników kaukaskich, był atak na lotnisku Domodiedowo. 24 stycznia 2011 r. na skutek samobójczego aktu detonacji ładunków wybuchowych na moskiewskim terminalu zginęło 35 osób, a ponad 150 zostało rannych (Rogoża, Żochowski, 2011). Kilka dni po tym wydarzeniu, do zorganizowania ataku przyznał się Doku Umarow, ówczesny lider Emiratu Kaukaskiego (Górecki, 2011b). Zamachowcy tym razem nie wystosowali żadnych żądań. Ich celem było przede wszystkim wywołanie strachu wśród zwykłych Rosjan. Był to jeden z większych zamachów organizowanych już po zakończeniu operacji antyterrorystycznej w Czeczenii (czyli po 2009 r.).

Od 2002 r. Federacja Rosyjska zaczęła wobec Czeczenii prowadzić tzw. politykę czeczenizacji. Wprowadzenie tej polityki wiązało się w dużej mierze z tym, iż przez całe lata 90-te XX w., rosyjskie działania wobec „niepokornej” republiki, miały charakter reaktywny (czyli były działaniami podejmowanymi w efekcie na kryzys, a nie zapobiegający jemu). Działania te, podejmowane za panowania Borysa Jelcyna oraz na samym początku prezydentury Władimira Putina, okazały się wysoce nieefektywne. Zastosowanie wariantu siłowego, nie przyczyniło się do stabilizacji wewnętrznej Republiki Czeczenii i nie zniwelowało zagrożenia terrorystycznego dla obywateli rosyjskich.

Głównym założeniem tzw. polityki czeczenizacji, jest obsadzanie przez Kreml najważniejszych organów władzy w Republice Czeczenii etnicznymi Czeczenami i danie im dużej niezależności wewnętrznej (Falkowski, 2004, s. 8). Ludzie ci, przy pomocy własnych struktur siłowych (które zostały utworzone za zgodą Władimira Putina), mają zapewnić stabilność republice. Dysponując niemal nieograniczoną władzą i ogromnymi środkami finansowymi (płynącymi wprost z budżetu Federacji Rosyjskiej), mają skutecznie eliminować wszelkie zagrożenie ze strony islamskich ekstremistów, tworzących po 2007 r. luźną strukturę organizacyjna, jaką jest Emirat Kaukaski (Malashenko, 2014). Oczywiście rodem, który odpowiadał (i nadal odpowiada) za skuteczne wdrożenie tej koncepcji jest klan Kadyrowów (początkowo Achmad, obecnie jego syn Ramzan) (Кадыров, 2016). Do dzisiejszego dnia, zarówno Achmad jak i obecny przywódca Czeczenii Ramzan Kadyrow są postrzegani przez 
bojowników kaukaskich jako najwięksi zdrajcy idei niepodległościowej. Trzeba jednak zauważyć, że autonomia, jaką obecnie de facto posiada ta niepokorna republika, jest nawet większa od tej, o jakiej marzyli Dżochar Dudajew czy Asłan Maschadow.

\section{Kto skuteczniej walczył z bojownikami kaukaskimi?}

W dwóch omawianych okresach (czyli w okresie sprawowania urzędu prezydenta przez Borysa Jelcyna oraz w okresie kiedy to Władimir Putin jest najważniejszą postacią życia politycznego) w Federacji Rosyjskiej istniało przekonanie, że terroryzm jest jednym z największych zagrożeń dla bezpieczeństwa i stabilności państwa. W dokumentach bazowych takich jak: konstytucja, ustawa federalna O bezpieczeństwie (z 1992 r.), czy też „Strategia bezpieczeństwa narodowego Federacji Rosyjskiej do 2020 r.” (z 2009 r.) znalazły się zapisy, mówiące o tym, że zadaniem państwa jest walka ze wszelkimi zagrożeniami terrorystycznymi i ekstremistycznymi. W jednym oraz drugim okresie przyjęto także ustawy (w 1998 r. O walce z terroryzmem oraz w 2006 r. O przeciwdziałaniu terroryzmowi), które w sposób kompleksowy regulowały kwestie z tym związane (zawarte w nich były definicje, czy też konkretne kompetencje poszczególnych organów wykonawczych czy ustawodawczych w walce z zagrożeniem terrorystycznym).

Wskazując podobieństwa, jeśli chodzi o dwa omawiane okresy, na pewno można też stwierdzić, że w Federacji Rosyjskiej od połowy lat 90-tych istniało przekonanie, że największym źródłem zagrożeń terrorystycznych jest Kaukaz Północny, a szczególnie Czeczenia. Dlatego też, aby zniwelować to zagrożenie, potrzebne było ustabilizowanie sytuacji w tym regionie. Warto jednak zaznaczyć, że stabilizację tą, starano się osiagnąć zarówno w jednym, jak i drugim okresie, zupełnie innymi metodami.

Wskazując z kolei różnice, można stwierdzić, że po doświadczeniach z końcówki lat 90-tych XX w. oraz z początku XXI w., Rosjanie zmienili strategię walki z terroryzmem pochodzącym z Kaukazu Północnego. Realizując tzw. politykę czeczenizacji, Władimir Putin chciał doprowadzić do sytuacji, w której to przedstawiciele samych narodów kaukaskich będą zwalczać terrorystów (Górecki, 2011a, s. 5). Najbardziej jaskrawym przykładem zastosowania tego wariantu jest oczywiście Czeczenia, w której to klan Kadyrowów (dysponując ogromnymi środkami z budże- 
tu federalnego) prowadził przez wiele lat skuteczną walkę z bojownikami kaukaskimi, doprowadzając do dużego ich osłabienia. To bowiem z Czeczenii (oprócz sąsiadującego z nią Dagestanu) wywodziło się najwięcej terrorystów, tworzących oddziały bojowników kaukaskich. Prowadzenie tzw. polityki czeczenizacji spowodowało, że konflikt, który przez wiele lat miał charakter rosyjsko-czeczeński, przybrał postać starcia wewnątrzczeczeńskiego. Trzeba jednak zaznaczyć, że polityka ta, jest skuteczna, kiedy na czele Czeczeni stoi Ramzan Kadyrow. Rodzą się poważne wątpliwości, czy będzie ona równie efektywna, gdy do władzy dojdzie inna osoba, która nie będzie umiała stworzyć tak silnego ośrodka władzy, jaki obecnie jest w tej rosyjskiej republice.

\section{Bibliografia}

Adamczyk S. (2011), Przeciwdziatanie terroryzmowi. Udzial żandarmerii wojskowej w krajowym systemie zwalczania zagrożeń terrorystycznych, w: Oblicza terroryzmu, red. T. Bąk, Kraków-Rzeszów-Zamość.

Bolechów B. (2012), Polityka antyterrorystyczna w świetle badań nad terroryzmem, Wrocław.

Brodowski J. (2006), Terroryzm a sprawa czeczeńska, w: Czeczenia - Rosja. Mity i rzeczywistość, red. J. Brodowski, M. Smoleń, Kraków.

Ciesielski S. (2006), Wojna w Czeczenii 1994-1996, w: Czeczenia-Rosja. Mity i rzeczywistość, red. J. Brodowski, M. Smoleń, Kraków.

Dmochowski T. (2013), Strategia bezpieczeństwa narodowego Federacji Rosyjskiej i jej ewolucja: ustawy Federalne „O bezpieczeństwie” z lat 1992 i 2010, w: Azjatyckie strategie bezpieczeństwa, red. J. Marszałek-Kawa, Torun.

Duraj N. (2015), Zróżnicowanie zadań jednostek odpowiedzialnych za zwalczanie terroryzmu na terytorium Federacji Rosyjskiej, http://wladzasadzenia.pl/2015/5/ zroznicowanie-zadan-jednostek-odpowiedzialnych-za-zwalczanie-terroryzmu-na-terytorium-federacji-rosyjskiej.pdf, 6.12.2016.

Falkowski M. (2003), Czeczenia a Rosja: znaczenie kwestii czeczeńskiej dla współczesnej Rosji, http://www.osw.waw.pl/pl/publikacje/prace-osw/2003-08-20/czeczenia-a-rosja-znaczenie-kwestii-czeczenskiej-dla-wspolczesnej, 7.12.2016.

Falkowski M. (2004), Kaukaz Pólnocny: rosyjski węzet gordyjski, http://aei.pitt. edu/58353/1/prace_16_3.pdf, 7.12.2016.

Falkowski M., Marszewski M. (2010), Kaukaskie „terytoria plemienne”. Kaukaz Pólnocny - cywilizacyjnie obca enklawa w granicach Rosji, http://www.osw. waw.pl/pl/publikacje/prace-osw/2010-04-14/kaukaskie-terytoria-plemiennekaukaz-polnocny-cywilizacyjnie-obca, 2.12.2016.

Falkowski M. (2015), Ramzanistan. Czeczeński problem Rosji, https://www.osw.waw. pl/sites/default/files/pw_54_pl_ramzanistan_net_0.pdf, 4.12.2016. 
Федеральный закон от 6 марта 2006 года „О противодействии терроризму” (2006), http://www.consultant.ru/document/cons_doc_LAW_58840/, 11.12.2016.

Федеральный закон от 25 июля 1998 г. „, О борьбе с терроризмом” (1998), http:// www.scrf.gov.ru/documents/17/30.html, 8.12.2016.

Федеральный закон от 28 декабря 2010 г. „, О безопасности” (2010), http://www. consultant.ru/document/cons_doc_LAW_108546/, 10.12.2016.

Górecki W. (2011a), „Pełzajaca” wojna domowa na Kaukazie Pótnocnym, http:// www.osw.waw.pl/pl/publikacje/komentarze-osw/2011-03-15/pelzajaca-wojna-domowa-na-kaukazie-polnocnym, 8.12.2016.

Górecki W. (2011b), Umarow wziąt odpowiedzialność za zamach na lotnisku Domodiedowo, http://www.osw.waw.pl/pl/publikacje/analizy/2011-02-09/umarowwzial-odpowiedzialnosc-za-zamach-na-lotnisku-domodiedowo, 5.12.2016.

Jagnieża A. (2014), Terroryzm w rękach Moskwy, http://www.defence24.pl/analiza terroryzm-w-rekach-moskwy, 4.12.2016.

Кадыров Рамзан Ахматович (2016), http:/www.kavkaz-uzel.eu/articles/85366/, 17.12.2016.

Konarzewska N. (2013), Terroryzm na Kaukazie Pólnocnym. Niekończqcy się konflikt?, http:/www.psz.pl/116-bezpieczenstwo/terroryzm-na-kaukazie-polnocnym-niekonczacy-sie-konflikt, 7.12.2016.

Kosta R. A. (2007), Terroryzm jako zagrożenie dla bezpieczeństwa cywilizacji zachodniej w XXI wieku, Toruń.

Kraj K. (2005), Rola Rosji w walce z terroryzmem międzynarodowym, w: Walka z terroryzmem $w$ świetle prawa międzynarodowego, red. K. Lankosz, M. Chorośnicki, P. Czubik, Bielsko-Biała.

Kuleba M. (2007), Szamil Basajew: rycerski etos a powinność żołnierska, Warszawa.

Laskowska K. (2009), Aktualny stan antyterrorystycznego ustawodawstwa w Federacji Rosyjskiej. Próba analizy i oceny, w: Terroryzm. Materia ustawowa, red. K. Indecki, P. Potejko, Warszawa.

Madej M. (2012), Zagrożenia asymetryczne - „nowy” problem bezpieczeństwa międzynarodowego, w: R. Kuźniar, B. Balcerowicz, A. Bienczyk-Missala, P. Grzebyk, M. Madej, K. Pronińska, M. Sułek, M. Tabor, A. Wojciuk, Bezpieczeństwo międzynarodowe, Warszawa.

Malashenko A. (2014), Islam in Russia, http://eng.globalaffairs.ru/number/Islam-inRussia-17002, 10.12.2016.

Markedonov S. (2013), The North Caucasus: The Value and Costs for Russia, http:// eng.globalaffairs.ru/number/The-North-Caucasus-The-Value-and-Costs-forRussia-16287, 13.12.2016.

Mickiewicz P. (2010/2011), Bezpieczeństwo wewnętrzne Federacji Rosyjskiej w rozwiqzaniach legislacyjnych i organizacyjnych, ,Rocznik bezpieczeństwa międzynarodowego", 2010/2011.

Обеспечение национальной безопасности, Стратегии национальной безопасности Российской Федеращии до 2020 года (2009), http://www.scrf.gov.ru/ documents/99.html, 9.12.2016. 
Patlewicz B. (2005), Zamach terrorystyczny w moskiewskim teatrze na Dubrowce, w: Kaukaz $w$ dobie globalizacji, red. A. Furier, Poznań.

Pietraś M. (2003), Bezpieczeństwo państwa w późnowestfalskim środowisku międzynarodowym, w: Kryteria bezpieczeństwa międzynarodowego państwa, red. S. Dębski, B. Górka-Winter, Warszawa.

Raś M. (2009), System bezpieczeństwa Federacji Rosyjskiej, w: Problemy bezpieczeństwa wewnętrznego i bezpieczeństwa międzynarodowego, red. K. M. Księżopolski, Warszawa.

Rogoża J., Żochowski P. (2011), Rosyjskie państwo wobec zamachu terrorystycznego na lotnisku Domodiedowo, http://www.osw.waw.pl/pl/publikacje/analizy/2011-01-26/rosyjskie-panstwo-wobec-zamachu-terrorystycznego-nalotnisku, 4.12.2016.

Słownik terminów z zakresu bezpieczeństwa narodowego (2002), Warszawa.

Уголовный кодекс Российской Федерации (1996), https://www.consultant.ru/document/cons_doc_law_10699/, 9.12.2016.

Wańczyk K. (2006), Polityka Federacji Rosyjskiej wobec Czeczenii, w: Czeczenia - Rosja. Mity i rzeczywistość, red. J. Brodowski, M. Smoleń, Kraków.

Wolska E. (2013), 10 lat po tragedii na Dubrowce, czyli jak nie przeprowadzać akcji ratunkowej, „Ostry Dyżur”, nr 1, t. 6.

Wyszyńska A. (2014), Podstawy prawne zwalczania terroryzmu w Federacji Rosyjskiej, w: Zwalczanie terroryzmu, red. M. Marszałek, J. Limanowski, Warszawa.

\section{Similarities and differences in combating Caucasian militants during the exercise of power by Boris Yeltsin and Vladimir Putin in the Russian Federation}

\section{Summary}

Analyzing the policy of the Russian Federation to the terrorist threat originating from the North Caucasus, it is clear that for many years Moscow has not established a coherent approach to solving this problem. In the last decade of the 20th century, Russia's policy consisted primarily in responding to the emerging crises. This policy led to the defeat in the first Chechen war and contributed to increased instability in the whole region of the North Caucasus. At the beginning of the 21 st century, Russia changed its strategies to combat terrorism rooted in the North Caucasus. Moscow began to implement the so-called Chechenization policy, assuming that the representatives of the Caucasian nations would fight the terrorists themselves.

Key words: Russian Federation, Islamic terrorism, North Caucasus, Boris Yeltsin, Vladimir Putin, Ramzan Kadyrov 
